\title{
Teachers' Indicators Used to Describe Professional Well-Being
}

\author{
Sacha Stoloff ${ }^{1}$, Maude Boulanger ${ }^{1}$, Élisabeth Lavallée $^{1} \&$ Julien Glaude-Roy $^{1}$ \\ ${ }^{1}$ Department of Physical Activity Sciences, Université du Québec de Trois-Rivières, Trois-Rivières, Canada \\ Correspondence: Sacha Stoloff, Université du Québec de Trois-Rivières, 3351, boul. des Forges, CP 500, \\ Departement of Physical Activity Sciences, Trois-Rivières (Quebec), G9A 5H7, Canada. Tel.: 1-819-376-5011, \\ ext. 3779. E-mail: sacha.rose.stoloff@uqtr.ca
}

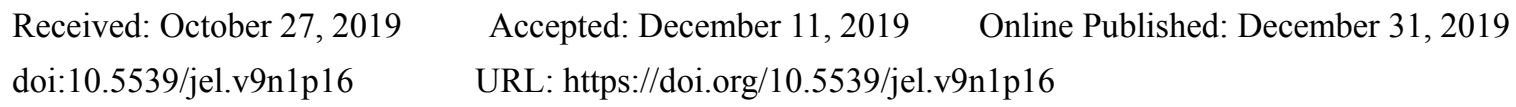

\begin{abstract}
The teaching profession has been studied and discussed from a problem-oriented point of view and cultivated by a problem-oriented scientific tradition. Years of research have enabled a better understanding of difficult teaching conditions and teachers' ill-being; an ideological and scientific shift, however, appears necessary to enrich and broaden our present knowledge. One particular question arises: which determinants optimize teachers' professional well-being? In response, our study seeks to identify indicators that allow teachers to create, maintain or restore a state of professional well-being. Our research objective thus aims to describe teachers' indicators regarding the "optimal functioning" that characterizes professional well-being (Seligman, 2011). The research protocol targets physical education teachers insofar as they are now recognized as leaders and models for promoting healthy lifestyles in schools and communities (MEQ, 2001). The methodology involved 5 focus groups composed of 37 teachers from 7 regions of Quebec. As the findings indicate, this approach allowed us to paint an integrative portrait of teachers' indicators relative to professional well-being. Two categories have proved effective in terms of professional well-being: the first is Self and includes 4 variables: meaning, positive emotions, engagement and vitality; the second is Others and includes 3 sub-categories: students, colleagues and school administration. The sub-categories comprise 6 variables divided as follows: positive relationships, learning, collaboration, transfer (specifically for the two first sub-categories), followed by vision and valorization for the third sub-category.
\end{abstract}

Keywords: professional well-being, teacher education, physical education, focus group

\section{Introduction}

Psychological health is divided into two poles: 1) psychological well-being, or the presence of a healthy mental state, and 2) psychological distress, or the presence of a mental health problem (Stamate, Brunet, \& Savoie, 2015). To examine psychological health, Stamate et al. (2015) distinguished three dimensions: Self, Others and Work. The pole concerning psychological distress has been studied and discussed with regard to teaching, thus facilitating knowledge advancement and a better understanding of the phenomenon of distress and ill-being. Teaching in Canada is currently beset by teachers' disengagement from the profession (Kamanzi, Barroso Da Costa, \& Ndinga, 2017), and the province of Quebec is experiencing the same difficult situation (Karsenti, Correa Molina et al., 2015). There are various impacts in terms of public costs (St-Arnaud, 2017), professional wear out (Lantheaume \& Hélou, 2008), exhaustion and burnout (Houlfort \& Sauvé, 2010). This research project was designed to face this state of psychological distress in the teaching profession, which has been a subject of debate for many years (Brassell, 2015; Tardif, 2014). Efforts to understand the situation suggest focusing on teachers' well-being and the ways it can be achieved (Goyette, 2014; Théorêt \& Leroux, 2014).

\subsection{Scope of Well-Being in the Teaching Profession}

\subsubsection{Relation to Self}

To discuss the first dimension regarding Self, Seligman (2011) presents "meaning" as the core element of well-being. In the teaching context, meaning involves identity building, social responsibility, roles played, and a desire to contribute to students' potential development by achieving objectives; it is therefore the element most highly valued (Goyette, 2016). Deviating from Seligman's definition (2011), which is "belonging to and serving something that you believe is bigger than self" (p. 12), this concept is also refered to as "the coherence between the person and the work she accomplishes, her expectations, her values and the everyday acts she performs in her 
environment" (Morin \& Gagné, 2009, p. 4) [free translation]. It would appear that, in a professional context, meaning rests on the need for coherence between personal values and those conveyed in the professional environment (Goyette, 2014). In the creation of meaning, character strengths are identified as the driving force and cornerstone of well-being (Goyette, 2014, 2016; Peterson \& Seligman, 2004).

In general, when occupational meaning is positively perceived by the teacher, $\mathrm{s} /$ he tends to be more emotionally engaged in the organization. Engagement is about "being one with the music, time stopping, and the loss of self-consciousness during an absorbing activity", (Seligman, 2011, p. 11), a state described as a sense of flow (Csikszentmihalyi, 2008). It is considered optimal when the affective, behavioural and cognitive dimensions complement each other (Houlfort \& Sauvé, 2010; Morin, Breault-Labbé, \& Brassard, 2013). A teacher's optimal engagement manisfestation could vary between self-realization, satisfaction and/or sense of accomplishment (Ngoya, 2016; Mukamurera \& Balleux, 2013).

Professional well-being is also fuelled by a self-determined motivation (Cenkseven-Önder \& Sari, 2009; Duchesne, Savoie-Zajc, \& St-Germain, 2005) involving the satisfaction of the three basic psychological needs (competency, autonomy, relationship). These needs play the role of mediator in well-being (Ntsame, Desrumaux, \& Boudrias, 2013; Stamate et al., 2015). This intrinsic motivation is stimulated when teachers are given the opportunity to use their talents, develop their competencies and assume responsibilities (Levesque, Blais, \& Hess, 2004; Mukamurera \& Balleux, 2013). This leads to positive emotions. The literature depicts positive emotions as an element privileged by teachers (Goyette, 2016; Sturmfels, 2009) which impacts their level of well-being (Seligman, 2011). Vitality, defined as "the level of energy available to the self", increases and becomes an indicator of health and motivation (Ryan \& Deci, 2008, p. 702). Various variables are involved such as feeling alive, full of life, energized, determined, alert and stimulated (Ryan \& Frederick, 1997).

Finally, relation to Self includes various dimensions supported by emotional intelligence at work. "Emotional intelligence (EI) encompasses an array of emotional competencies that facilitate the identification, processing and regulation of emotion and may enhance successful stress management, as well as augmentation of teachers' well-being and classroom performance" (Veseley, Saklofske, \& Nordstokke, 2014, p. 81). Emotional intelligence, by its very nature, represents the link between relation to self and relation to others.

\subsubsection{Relation to Others}

To discuss this second dimension, Stamate et al. (2015) present relation to others as a determining aspect of teachers' professional well-being. Regarding this issue, the literature highlights three particular variables: 1) school climate, 2) positive relation to colleagues and 3) positive relation to students.

First, Yildirim (2014) maintains that a positive school climate, also called a work environment, promotes the professional well-being of all personnel including teachers. A climate of this kind is created by positive feedback and interactions with students and colleagues (Yildirim, 2014; Sturmfels, 2009). Another contributing factor is a mobilization style on the part of the administration that encourages professional engagement (Duchesne \& Savoie-Zajc, 2005) and self-determination (Levesque, Blais, \& Hess, 2004) by means of unifying leadership (Willmore, 2007). A collaborative climate of exchange with colleagues and the administration therefore plays a crucial role vis-à-vis the different actors (Wimberley, 2011) and positively affects teachers' level of satisfaction and engagement (Murielle, Ntsame, Desrumaux, \& Boudrias, 2013; Cenkseven-Önder \& Sari, 2009; Huang \& Waxman, 2009).

Second, Janosz, Thiebaud, Bouthillier and Brunet (2004) approach relational climate from the perspective of warmth, respect and pleasure in interpersonal relationships. At this relational level, one finds strength in positive relationships between colleagues; these are characterized by peer support, team spirit and interpersonal compatibility (Ngoya, 2016; Goyette, 2014, 2016; Yildirim, 2014; Sturmfels, 2009). This is generally accompanied by peer recognition and valorization of one's work, two variables that strongly affect teachers' professional well-being (Ngoya, 2016; Sturmfels, 2009).

Third, Janosz et al. (2004) also mention positive relationships with students as a central variable conducive to professional well-being. Goyette (2016), moreover, shows that such relationships create a bond of trust conducive to learning, notably through the kind of teaching activities the students' value.

\subsection{Issue and Corresponding Research Design}

The teaching profession is in need of restorative and constructive knowledge on well-being (Goyette, 2014). To increase understanding, improve teachers' well-being and reduce disengagement, it is essential to shed light on how this phenomenon manifests in the field of teaching.

It's certain that significant knowledge has resulted from a focus on teachers' professional well-being in the last 
decade; this represents an ideological shift compared with health research, which, up to then, had been exclusively interested in understanding problems and diseases (Seligman, 2011). Thanks to this shift, however, professional well-being is currently studied across numerous theoretical frameworks and conceptual referents other than well-being per se. The concept is therefore difficult to define and, in turn, difficult to examine systematically in order to pinpoint the core determinants. What's more, the concept of professional well-being prompts different definitions when studied through multiple lenses, sometimes producing excessive correlations.

To investigate the issue and narrow the concept to a tangible framework, our integrative research project addresses professional well-being from the angle of positive psychology theory while using an inductive research design. The research question is: Which variables do teachers rely on to optimize professional well-being? Our objective, in response, is to describe teachers' indicators in terms of the "optimal functioning" that leads to professional well-being. Teachers were questioned about professional well-being, the ways to achieve it and the key indicators.

\subsection{Conceptual Framework}

The present study is rooted in positive psychology, which has proved useful since 2000. In psychological research, this theory enables researchers "to discover and promote factors that allow humans and societies to flourish" (Gaucher, 2010, p. 13) [free translation]. In other words, positive psychology focuses on individuals who function well, who flourish, who persevere despite setbacks (idem, 2010). While difficulties in many fields are often well documented and offer interesting insights into the changes needed, Seligman (2002) proposes to rebalance knowledge through a study of the individual based on the positive aspects of human nature. To this end, positive psychology enables a shift of perspective in research and education together with a better understanding of the source of success and the means to achieve it. This innovative shift constitutes a bold epistemological position that results in educational and flexible methods of action which teachers can implement.

A core concept in positive psychology theory is well-being (Csikszentmihalyi, 2008; Seligman, 2011), which has apparently been an effervescent concept over the years. Interestingly, Seligman's work (2011) includes five components of well-being as presented in the PERMA model, with each letter representing a key component:

- Positive emotions: the capacity to view different situations from a positive perspective, to be optimistic, which nurtures positive emotions;

- Engagement: the emotional capacity to live in the moment, absorbed in the flow of a task or activity, which creates a sense of immersion in time and space;

- Positive Relationships: the social support available when facing different life situations, characterized by strong emotional and physical interactions which solidify one's safety net;

- Meaning: the capacity to make sense of one's life by clarifying the meaning of one's actions and implications, leading to a purposeful existence; adjusted by Morin and Gagné (2009) to fit the professional context;

- Accomplishment: the capacity to identify reachable goals and realistic ambitions, which results in pride and lasting fulfillment when accomplished.

\section{Method}

\subsection{Research Design and Participants}

Our study was designed using a qualitative approach favouring induction (Paillé \& Mucchielli, 2008) to enable a descriptive and interpretative method for achieving our research objectives (Savoie-Zajc, 2009). To favour induction and limit theoretical influence, coding was ensured by analysts new to the concept and lacking knowledge of definitions, frameworks, or models regarding well-being. This approach privileged the emergence of themes directly related to content.

The sample was intentional: solicited participants were physical education (PE) teachers with a positive approach to teaching $(n=37)$. Sociodemographic variables show a gender distribution of $57 \%$ women and $43 \%$ men, a teaching level of $86 \%$ primary schools, $8 \%$ secondary schools and $6 \%$ former teachers who had become regional pedagogical consultants (also known as regional leaders), and an employment status of $67 \%$ permanent, $30 \%$ contract and $3 \%$ substitute teachers. The mean age is 36.62 years old $(\sigma=+-10.62)$. The deprivation index is 5.94/10, where 1 equals privileged and 10 equals very deprived $(\sigma=2.96)$.

In this first phase of the project, PE teachers were targeted because they are health leaders in the teaching community. Other teachers will be targeted in a second phase to complete the investigation. Recruitment was done in five regions of Québec by PE leaders who contacted potential participants and organized meetings. Information about the project (goal, methodology, outcomes and ethical considerations) was forwarded to them 
online along with a descriptive sheet pre-approved by the Ethics Comittee (CER-17-235-07.05). The consent form was signed on the day of the focus group. In total, $37 \mathrm{PE}$ teachers agreed to participate in the study, representing 7 of the 17 administrative regions of Quebec (Abitibi-Témiscamingue, Capitale-Nationale, Estrie, Lanaudière, Laurentides, Laval, Outaouais).

\subsection{Tool}

The focus group was conducted with these PE teachers to ensure the support of primary actors and collaborators that is essential for optimizing knowledge mobilization and transfer (Stoloff, Boulanger, Roy, \& Rivard, 2016). It was used to meet the objective concerning teachers' representations and experiences of the "optimal functioning" that leads to professional well-being. This tool was chosen because it highlights experiences, opinions and concerns (Van der Maren, 2010) via focused discussion and collective reflection.

Five focus groups were conducted to initiate a structured exchange; each was composed of 6 to 12 participants, ensuring valid conditions (Barbour \& Kitzinger, 1999) and each lasted approximately 90 minutes. The interview was based on teachers' beliefs and knowledge regarding optimal functioning. Over 7 hours of discussion and 125 pages of transcription were analyzed.

\subsection{Analysis Strategy}

The content analysis was conducted based on themes (Paillé \& Mucchielli, 2008) using NVivo10 software. The process was based on emerging themes. Intercoder reliability was 91\% of the initial coding (Deslauriers, 1991); inconsistencies were then recoded until intercoder agreement was reached.

\section{Results}

Teachers use two categories of indicators to identify their state of well-being in relation to Self and Others. They identify twelve variables of well-being to classify indicators. For Self, teachers address well-being through four variables described as meaning, positive emotions and feelings, engagement and vitality. For Others, teachers address well-being through eight variables divided into three sub-categories. First, variables regarding students include positive relations, learning and transfer. Second, variables regarding colleagues include positive relations, collaboration and transfer. Third, variables regarding school administration include vision and valorization. These key variables are presented in Figure 1.

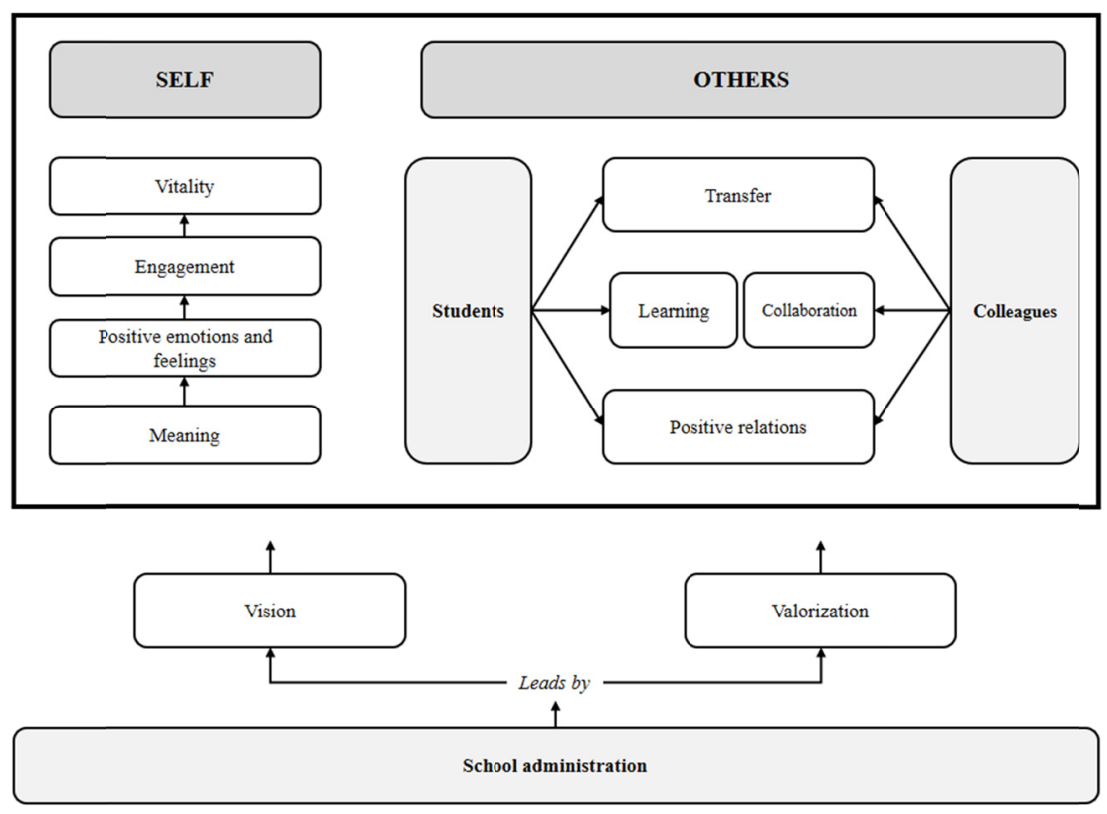

Figure 1. Key variables of teachers' professional well-being 


\subsection{Relation to Self}

To begin, the Self category includes all items dealing with the teachers themselves and is composed of four variables: 1) meaning, 2) positive emotions and feelings, 3) the teacher's optimal engagement in work, and resulting 4) vitality.

\subsubsection{Meaning}

The first variable concerns the meaning found in their work and career. In this regard, teachers say they have a positive perception of their role, which indicates their profession's meaningfulness and the confidence and pride they derive from it. One teacher explained that "belief in what you do, (...) belief in what you contribute" (FG1-13P17, Note 1) is an indicator of the meaning attributed to one's choice of career. In general, teachers discussed different components testifying to this occupational meaning, notably through 1) their conviction they made the right choice of career, 2) the fulfillment found in their work, 3) the importance accorded to it, 4) the impacts of their actions, and 5) the pride and confidence they experience. Indeed, one teacher stated that "When you choose a profession, you're acknowledging what drew you to that profession. It's seeing the potential in what you do" (FG1-9P17). Thus, an individual acquires a sense of well-being through lived experiences, such as explained by a teacher:

When you go to work every morning, you know you have a purpose. You know you're going to influence people, young people especially. It's feeling that you're going to be useful. I think that's what creates a real sense of well-being (FG5-1P1).

The teachers also discussed a key element for understanding professional well-being in terms of meaning, and the alignment between personal values and school values. The following words illustrate its importance:

My teaching is closer to my values as a professional (...). I have principles, I have values, I have approaches. The school where I'm happy is the one whose values and principles are directly [in line with] what I am as a professional (FG4-5P3).

\subsubsection{Positive Emotions and Feelings}

The second variable concerns the positive emotions and feelings teachers experience when performing their tasks. Their professional activity and the role they play are, in fact, sources of positive emotions that allow them to perceive various situations from a positive and optimistic perspective. The emotions identified are happiness, joy and the pleasure of personal accomplishment. Their work is fulfilling, and the resulting enthusiasm impacts other areas of their life as well. One teacher was describing positive emotions by saying:

The pleasure of teaching, excitement, engagement and devotion, I'd say. You know, I'm not in a good mood just at home. I'm in a good mood everywhere else in my life (FG1-17P17).

Furthermore, the teachers say they are fortunate to do what they do and feel their work is a source of nourishment. Thinking about their job makes them happy because it generates good feelings and enthusiasm.

These positive emotions combine with the good feelings they get from work. Concretely, the teacher's role and tasks performed give way to a wide range of positive feelings encompassing self-determination, accomplishment, creative freedom, competency, control and, finally, a sense of self. For example, one teacher discussed sense of accomplishment as an indicator of well-being by explaining that "it's the sense of accomplishment at work. Being able to realize your potential as a professional at work. Being happy there. Seeing where you're from and where you're headed, then fulfilling yourself through the things you do" (FG2-1P8). Also, another teacher framed the sense of freedom as follows:

Having the opportunity and freedom to be creative, creating the kind of teaching you want, creating new situations, trying things that work or don't work, making adjustments (...). For me, my gymnasium is a workshop. I try to be creative there (FG2-6P9).

\subsubsection{Engagement}

The third variable deals with optimal engagement, defined as the emotional capacity to experience the present moment by becoming so absorbed in a task and activity that one loses all notion of time and space. In the teachers' words, this situation is produced by a state of flow that occurs during optimal functioning at work; they describe this state as timelessness, with an accelerated rhythm, or on the contrary, a stopped rhythm. On one hand, teachers say that "you lose the notion of time despite being in a place where time is everywhere" (FG2-3P6), which refers to the idea of timelessness; and on the other, that "the days go by very quickly. Well-being is also this: watching your day pass so quickly that you just want more" (FG2-2P6). Still, another teacher describes this optimal engagement as a moment when nothing else exists; he feels a refreshing emptiness: "You clear your head completely because 
you're in the moment with your students, in the gymnasium experiencing something that clears your mind, that refreshes you" (FG2-4P6). The experience of flow during optimal functioning is quasi-addictive: it leaves the person with a desire for more: "you feel like continuing on, like becoming lost in time and space" (FG4-2P7). When functioning is no longer optimal due to a destabilizing situation, a state of well-being apparently allows teachers to regain control relatively easily, to "try to assume control as quickly as possible" (FG2-9P9). Thus, they think back to former experiences and choose a solution that worked in the past. In consequence, they slow the pace of their activities and take "time to do things" (FG4-1P7).

\subsubsection{Vitality}

The fourth variable concerns vitality; it derives from the first three variables and deals with the physical and psychological effect of optimal functioning at work. Teachers say vitality is reflected in their level of energy, serenity, healthy fatigue and enthusiasm about going to work each day. During a group interview, one teacher stated with regard to level of energy that "I'm already full of energy when I wake up, then at the end of the day I still have a lot of energy to spend (...) It's as if work days were nourishing" (FG2-1P8). Teachers even mention a healthy fatigue felt during optimal functioning, a fatigue that comes from a busy day but doesn't lead to exhaustion: "You're tired, but you still have energy. It's a different kind of tiredness" (FG1-5P15). In fact, this experience of vitality may impact a teacher's long-term vision of plans for the future. One teacher maintained, for example, that he did not view the prospect of his coming retirement as a relief, which meant his choice of career was sound. On the subject of vitality, he stated: "as for me, I never feel like I'm forced to go to work" (FG5-2P7). Finally, it's interesting to note that, in order to maintain this vitality, certain teachers stress the importance of sleep, which they use as both an indicator of well-being (because they sleep well or enjoy restful sleep) and a privileged strategy to create or recover a state of well-being.

\subsubsection{Summary}

To conclude the discussion of the theme regarding Self, the key findings are presented in Table 1.

Table 1. Description and indicators of well-being for variables regarding Self

\begin{tabular}{|c|c|c|}
\hline Variables & Description & Indicators \\
\hline Meaning & $\begin{array}{l}\text { Positive perception of role, which } \\
\text { signifies profession's } \\
\text { meaningfulness along with the } \\
\text { confidence and pride derived from } \\
\text { it }\end{array}$ & $\begin{array}{ll}\text { - } & \text { Conviction about choice of career } \\
\text { - } & \text { Fulfillment derived from work } \\
\text { - } & \text { Importance accorded to work } \\
\text { - } & \text { Positive impacts of actions } \\
\text { - } & \text { Pride and confidence experienced } \\
\text { - } & \text { Alignment between personal and school values }\end{array}$ \\
\hline $\begin{array}{l}\text { Positive emotions and } \\
\text { feelings }\end{array}$ & $\begin{array}{l}\text { Positive effect and optimistic } \\
\text { reaction in various situations }\end{array}$ & $\begin{array}{l}\text { Emotions: happiness, joy, pleasure, fulfillment, } \\
\text { enthusiasum, feeling fortunate, sense of nourishment } \\
\text { Work-related feelings: self-determination, } \\
\text { accomplishment, creative freedom, competency, } \\
\text { control, sense of self }\end{array}$ \\
\hline Engagement & $\begin{array}{l}\text { Capacity to experience the present } \\
\text { moment by becoming so absorbed in } \\
\text { a task and activity that all notion of } \\
\text { time and space is lost }\end{array}$ & $\begin{array}{ll}\text { - } & \text { Timelessness } \\
\text { - } & \text { Accelerated rhythm } \\
\text { - } & \text { Stopped rhythm } \\
\text { - } & \text { Emptiness } \\
\text { - } & \text { Ease in regaining control }\end{array}$ \\
\hline Vitality & $\begin{array}{l}\text { Positive physical and psychological } \\
\text { effect of optimal functioning at } \\
\text { work }\end{array}$ & $\begin{array}{ll}- & \text { Energy } \\
- & \text { Serenity } \\
- & \text { Healthy fatigue } \\
- & \text { Sleep }\end{array}$ \\
\hline
\end{tabular}

With respect to these findings, it seems important to stress the notion of healthy imbalance highlighted in teachers' comments. Healthy imbalance is characterized by the relative weight of positive elements, which must be higher than the relative weight of problematic elements. Contrary to balance, a healthy imbalance contributes to a state of well-being in which positive experiences outweigh the negative ones. One particular teacher offers an example of imbalance with the words: "teaching's more fun than the workload you have to carry out" (FG1-5P16). 


\subsection{Relation to Others}

Before describing our findings on the different categories regarding Others, we note that, generally speaking, society's perception of the role of PE teachers appears to have a decisive impact on their professional well-being. To this effect, one teacher mentions that the positive transformation of society's perception had a favourable impact on him, notably because it harmonized with the meaning he finds in his profession. The following extract demonstrates this societal shift and how it affects him:

I see $[\mathrm{PE}]$ has been getting a lot of recognition in the last few years. From our school board, from parents and the media, we're more and more present because of healthy lifestyle habits. It seems our role has become more important (...). This makes me feel more appreciated: "Well, finally, they recognize we have a central role to play in students' learning" (FG5-5P6).

Overall, this category integrates the effect of perceptions and actions that others have on PE teachers' professional well-being. It comprises three sub-categories and eight variables. The first sub-category concerns students and is divided into three variables: positive relations, learning and transfer. The second relates to colleagues and refers to both teachers and administrative personnel; this is likewise divided into three variables: positive relations, collaboration and transfer. The third sub-category concerns the school administration and includes two variables: vision and valorization of the teachers themselves and the teaching profession.

\subsubsection{Relation to Students}

\section{Positive relations}

Continuing on, our findings uncover the determinants of well-being associated with relation to students. First, the positive relations variable examines how the quality of said relation is a beneficial factor in teachers' work. On one hand, teachers approach this variable through positive contact with students, expressed by a friendly presence, looks, smiles, physical contact and proximity, or discussions on personal subjects. One teacher stated that "for me, being able to develop a positive relation with each student greatly increases my sense of well-being at school" (FG2-3P1). On the other hand, they discuss the sense of nostalgia they experience during a separation from their students, hence the opposite of the pleasure of proximity. What's more, these bonds tend to deepen over the years as they come to know the students better. Consistent with the idea of nostalgia, one teacher used the example of the end of a school year when "it was the hardest year for leaving my students" (FG2-6P2). In addition, the subject they teach gives teachers a privileged status in the eyes of most students, as attested by a teacher who commented that "We [physical education teachers] have a particular status, it really makes you feel good. Each student you meet in the course, you feel you're appreciated" (FG5-2P1). In brief, a positive relation to students is an important expression or indicator of well-being at work.

\section{Learning}

Next, the learning variable refers to students' expressions of learning in any form: perseverance, excellence, success, progress, or even motivation. Teachers' professional well-being seems to be affected by level and type of learning made by students since they are indirectly actors of the learning process. In other words, student achievement demands that teachers plan and implement stimulating and innovative conditions which promote learning for all. Teachers stress student achievement as the crucial element of their well-being at work. One person in particular commented that "when a student succeeds in a motor exercise that was difficult for him, and his eyes show he's very proud of himself, I feel a sense of pride and well-being for sure" (FG3-1P2). Student achievement used as an indicator of learning also refers to the link between the meaning a teacher assigns to his/her profession and the fulfillment of professional expectations. To this end, the teacher is responsible for implementing optimal conditions during the teaching-learning process:

When you manage to get students interested in a subject they really don't care for. Example: jogging. But you motivate them so much, you introduce it so positively, you make it sound like so much fun with exercises, exciting activities, games... that finally they end up enjoying it and even excel during a test. Then you say to yourself: "Wow, OK, that's terrific" (FG3-5P2).

In the end, students' expressions of learning that nourish professional well-being also occur during moments when the right conditions allow students to develop their motivation and perseverance to excel. One teacher expressed learning indicators this way: "With my subject, which is physical education, it's when I manage to have a student persevere, to have a student excel" (FG4-5P2).

Transfer

The third variable in the sub-category for students deals with transfer. This variable comprises all items having to 
do with how content learned in a PE course transfers to student's free periods in school or everyday life. Teachers believe transfer can take place both in the short term, i.e., during the same day or week, and in the long term, i.e., when a former student returns to see the teacher several years later. One teacher gave the following example of a short-term transfer:

I said good-bye to them in the bus and then, one said to me: "Hey Mario (Note 2), tonight I'm doing Parkour." And I was ecstatic because we had finished a whole learning situation on Parkour, and now he's registered in a Parkour class. I gave him resources. I told myself I managed to create a transfer in that student's life (FG4-1P2).

These instances of transfer are privileged moments that go far to nurture teachers' well-being. Here, the impact of their teaching is reflected in the activities chosen by students outside structured and formalized PE courses.

Summary

To conclude the discussion of the theme regarding Others, specifically students, the key findings are presented in Table 2.

Table 2. Description and indicators of well-being for variables regarding others, specifically students

\begin{tabular}{llll}
\hline Variables & Description & \multicolumn{2}{l}{ Indicators } \\
\hline $\begin{array}{l}\text { Positive } \\
\text { relations }\end{array}$ & $\begin{array}{l}\text { Positive bond between teacher and } \\
\text { students }\end{array}$ & $\begin{array}{l}\text { - Positive contacts: friendly presence, looks, smiles, physical contact and } \\
\text { proximity, discussions on personal subjects, privileged status in the eyes of students }\end{array}$ \\
\hline Learning & $\begin{array}{l}\text { Students' process and product } \\
\text { experience leading to success }\end{array}$ & - & Sense of nostalgia: dreading separation or looking forward to being united \\
& $\begin{array}{l}\text { Cocess: expressions of motivation and perseverance } \\
\text { Product: expressions of excellence, achievement, progress, success }\end{array}$ \\
\hline Transfer & $\begin{array}{l}\text { Content learned in PE courses } \\
\text { transfered to student's free } \\
\text { periods in school or everyday life }\end{array}$ & $\begin{array}{l}\text { - } \\
\text { their life }\end{array}$ \\
& &
\end{tabular}

\subsubsection{Relations with Colleagues}

Positive relations

As with positive relations regarding students, the findings here reveal determinants of well-being that are linked to relations with colleagues, a factor beneficial to teachers' well-being as well. Content is based on the set of items dealing with the quality or importance of the bond between PE teachers and their colleagues as a source of recognition, confidence, support, positive influence and sense of belonging. On the other hand, the items also deal with PE teachers' reputation and its impact on their colleagues.

Many participants mentioned the extent to which peer recognition positively impacts their state of well-being. As for all teachers, such recognition has to do with the very nature of their role as teachers, illustrated by the following: "Basically, it feels great when others acknowledge what we do. It's [PE lessons] a time of learning like any other" (FG1-7P7). This recognition of their work enhances the importance they feel of their status in school: "Our role, our work, our status are seen as important. We're very important in the school" (FG5-3P7). This statement is associated with both the significance of their role in the school and their felt sense of belonging. Along these same lines, the motivation and level of engagement of peers positively impacts the well-being of the teachers interviewed, encouraging them to leave their comfort zone and increasing their own motivation and level of engagement. As one teacher observed:

I'm in a fantastic school where the teachers are fantastic. They do more than what's required. So, for me, that's super-motivating and it makes me want to try things I might never have dared try before (FG3-3P4).

Thus, positive relations with others, via assimilation to a group's dynamic, potentially motivates individuals to experiment with new ideas. As well, it appears that the positive influence of PE teachers may, in turn, influence the group's dynamic. A teacher commented on this effect, stating: "I try to contaminate them a little through positivism, through projects, through other colleagues. I know I can contaminate" (FG1-10P20). From these teachers' words one infers that positive influence is a two-way street, exerted from group to teacher and teacher to group. In general, positive relations are able to stimulate, motivate, positively influence and persuade PE teachers to try new things. This is evident in the collaborations discussed in the following section. 


\section{Collaboration}

Positive relations promote mobilization between colleagues. Demonstrations of collaboration seem to positively impact PE teachers' well-being in that they motivate engagement in the implementation of projects and smooth functioning. Collaboration derives from three determinants: interest in projects, participation in these projects and sharing of ideas and content. As the following extract shows, collaboration is an association of partners who work together towards a particular goal and share the consequences both good and bad:

In effect, we got together and tried something from scratch. We thought of it together, set it up together, prepared it together, taught it together and messed up together (...). I find that when you're part of a team, it goes over better than when you mess up alone (...). You're able to change the way you do things a little and see different perspectives sometimes, and that helps. And sometimes if things don't work out, you can laugh about it, you can relativize (FG4-3P5).

This collaboration has the added value of helping a teacher overcome possible isolation, notably through the co-teaching approach, which appears to be increasingly important in functioning modalities. This form of collaboration positively impacts professional well-being through the sharing of ideas and responsibilities: "Well-being also means sharing with another colleague. You know, there's starting to be more and more team teaching. I feel less and less alone in my office" (FG4-5P5). Collaboration is also discussed in terms of mutual aid, for example, the support offered to new teachers just starting out. To this effect, a teacher described the situation in his school where "the two new teachers we have this year, the two young ones who just got their degree, get a fabulous amount of support and supervision. We share super well, and it's not just me" (FG4-13P5).

Transfer

The category concerning relation to others highlights the idea of transfer from the PE course to the classroom context of titular teachers in terms of both the content conveyed by PE teachers and the cognitive and motor skills learned by students. One teacher, for example, reports the testimony of a kindergarten teacher colleague who told him that "the juggling you have them [the students] do in your gym improves their handwriting ability and their capacity to see improvement by themselves" (FG1-5P8). To sum up, PE teachers evoke the positive influence of subsequent transfers, especially when they experience coherence between the meaning of the profession, the positive relations among colleagues and the transfer itself. A productive interrelationship appears to nurture their professional well-being.

Summary

To conclude the discussion of this theme regarding Others, specifically colleagues, the key findings are presented in Table 3.

Table 3. Description and indicators of well-being for variables regarding Others, specifically colleagues

\begin{tabular}{|c|c|c|}
\hline Variables & Description & Indicators \\
\hline Positive relations & $\begin{array}{l}\text { Positive bond between teacher } \\
\text { and colleagues }\end{array}$ & $\begin{array}{ll}\text { - } & \text { Source of recognition, confidence, support, and sense of belonging } \\
\text { - } & \text { Positive influence } \\
\text { - } & \text { Positive reputation }\end{array}$ \\
\hline Collaboration & $\begin{array}{l}\text { Association where partners } \\
\text { work together towards a } \\
\text { particular goal and share the } \\
\text { consequences }\end{array}$ & $\begin{array}{l}\text { - } \\
\text { - } \\
\text { - } \\
\text { Enables smooth functioning } \\
\text { these projects and sharing of ideas and content } \\
\text { - } \quad \text { Offers mutual aid } \\
\text { - } \quad \text { Overcomes possible isolation }\end{array}$ \\
\hline Transfer & $\begin{array}{l}\text { Content learned and skills } \\
\text { developed in PE courses } \\
\text { transfer to classroom context }\end{array}$ & $\begin{array}{l}\text { - } \quad \text { Content transfer by titular teachers } \\
\text { - } \quad \text { Cognitive and motor skills transfer by students }\end{array}$ \\
\hline
\end{tabular}

\subsubsection{Relation to School Administration}

\section{Vision}

The third sub-category regarding relation to others concerns one's relation to the school administration. The elements that positively affect PE teachers' sense of professional well-being are highlighted in a set of items dealing with leadership and the administration's ability to inspire a common vision. One teacher described it as follows: 
My boss, my manager, my captain, the one above me...this helps create my sense of confidence. I know that with my leader above, we'll work together. She leads us together, us teachers, towards the same objective. She manages us so well, she leads us so well, that we're all excited about the same thing. We're not all scattered in different directions (FG1-2P13).

An administration that offers leadership is supportive of PE teachers. In fact, with regard to the explanations given, properly exercised leadership encourages all members of the school team to pursue a shared objective and adhere to the school's mission.

In addition to leadership, valorization of teachers' point of view appears to promote professional well-being as well. The teachers discussed the administration's attitudes of positive reinforcement, which translated into valorization of professional autonomy. To this effect, the administration's support is demonstrated through its encouragement, availability, confidence and openness. One teacher attested to his professional well-being in these words: “...when you prepare your courses, when you prepare your school year, when you do your planning, you know it's going to be OK. So, when [your principal] supports you, you get a sense of well-being that's really important" (FG5-4P6). This autonomy is expressed in teachers' freedom of action, the result of constant support by a principal who encourages proactivity and professional creativity. In one notable case, a teacher mentioned that her principal had acknowledged the proactivity of PE teachers in creating and implementing projects and activities in and for the school with the words: "You are the soul and heart of this school" (FG5-3P6).

\section{Discussion}

\subsection{Well-Being as a Framework}

The findings highlight two main categories that retain our attention: Self and Others. The latter category subdivides into three: students, colleagues and school administration. We note that the sub-category for school administration supports and anchors the elements affecting teachers' well-being. Each variable is discussed in the following paragraphs together with its possible links.

\subsection{Self}

\subsubsection{Meaning}

The findings of the present study underscore meaning as a determining element in the manifestation of well-being. It is expressed by teachers' conviction regarding their choice of career, the importance they accord their work, the impacts of their actions and their sense of self-realization, pride and accomplishment. In keeping with Morin and Gagné (2009), meaning is based on an individual's expectations, values and actions; it therefore becomes reality when the meaning of the profession is clear and takes shape through lived experiences. A key dimension for understanding professional well-being in relation to occupational meaning is the possible compatibility between personal values and the values of the school, as concluded by Goyette (2014).

\subsubsection{Positive Emotions and Positive Feelings}

Generally speaking, positive emotions in work appear to be an indicator of stimulating activity. Thoughts about work lead to a feeling of happiness because such thoughts are positive, generate good feelings and create a desire to work. These positive emotions are variously expressed by happiness, joy, pleasure and pride. Interestingly, positive emotions induced and fuelled by or at work seem to be related to teachers' capacity to perceive situations positively, as discussed in Seligman's work (2001). One might be excused for questioning whether good feelings like these are available to all, or if they depend instead on what Vesely et al. (2014) term emotional intelligence.

Furthermore, our findings reveal that positive emotions closest to the professional context and derived from the professional act recall feelings experienced during optimal functioning at work. Discussions of these feelings stimulated by the professional act, including self-determination, accomplishment and competency, are widespread in the literature, given that numerous studies use them as a theoretical framework for studying professional well-being. To these studies, our findings add newly-emerging self-perceptions, notably, creative freedom and sense of self. Further research is needed to define and describe these two emotional states more precisely.

\subsubsection{Engagement}

In keeping with Seligman (2011), our study's findings show that engagement translates into a person's emotional capacity to live in the present moment. When performing an action, a person is absorbed by the task and activity to the extent that $\mathrm{s} /$ he loses the notion of time and space. In a state of well-being, optimal engagement refers to the idea of timelessness as involving not only an absence of time, where nothing else exists, but also a refreshing sense of emptiness. This phenomenon echoes the notion of flow described by Csikszentmihalyi (2008). The experience of flow during optimal functioning at work is quasi-addictive: it leaves the person with a desire for more. 
Conversely, during non-optimal functioning due to a destabilizing situation, it would seem that a state of well-being gives teachers the strength to regain control of a situation by accessing their repertoire of successful experiences, slowing the pace of their activities and taking the time to search for solutions.

\subsubsection{Vitality}

The teachers say their vitality manifests in a number of ways: high energy level, sense of serenity, healthy fatigue after a busy day and, finally, their desire and readiness to return to work each day. These variables complement those described by Ryan and Frederick (1997), and add to the notion of vitality in a way that it closely resembles that of enthusiasm, which authors have described as an affective force (Morin, Breault-Labbé, \& Brassard, 2013). On the whole, it is clear that teachers relate to vitality on a physical and psychological level as a manifest of optimal functioning at work, which reminds us of the initial definition given by Ryan and Deci (2008), as the level of energy available to the Self.

Teachers underscore the importance of the vitality variable since it is both an indicator of well-being and a strategy for privileging, creating or rediscovering a state of well-being. Surprisingly, the antecedent literature fails to take vitality into account when describing professional well-being.

\subsection{Others}

\subsubsection{Positive Relations}

The positive relations variable indicates how the quality of relationships benefits teachers' work. Yildirim (2014) and Sturmfels (2009) addressed positive relations as a vector of the school climate; in terms of our study's findings, it is a bilateral variable concerning students and colleagues. For students, bonds are expressed by various forms of positive contact: a congenial presence, looks, smiles, physical contact and proximity, discussions on personal subjects, and finally, relationships that deepen over the years. This recalls the anchorings described by Neufeld and Maté (2005) when presenting the theory of attachment, that is, the use of feelings, physical and emotional proximity, belonging and importance accorded to an individual. In teaching, the same conclusions demonstrate the importance of positive relationships for promoting class management (Stoloff, 2016) and learning (Goyette, 2016).

As regards colleagues, teachers in our study address the relational variable via peer group dynamics. Complementing the work of Janosz et al. (2004), the studies' findings show that positive relations can potentially have a two-way impact: peers on teacher and teacher on peers. Their effect is to stimulate, motivate, positively influence and persuade PE teachers to risk trying new things. Here, attachment is described more in terms of belonging and importance of one's role.

\subsubsection{Learning/Collaboration}

Interestingly enough, positive relations tend to derive from the meaning accorded to the profession. In the section on Self, teachers discussed their convictions regarding their choice of career and the impacts of their action. In this section, a sense of well-being is attained by learning or collaborating (based on the nature of the relation students/colleagues). Indeed, with regard to students, teachers mention learning as the essential proof of their well-being at work. Accordingly, the teacher is responsible for planning and implementing conditions that promote learning. The student's success then becomes the teacher's success and nurtures his or her professional well-being.

At the same time, teachers evoke collaboration with colleagues as an expression of a state of well-being. Practically speaking, a healthy collaboration motivates them to implement projects and oversee their successful completion. For teachers, collaboration is an association in which partners work together to achieve an objective and share the consequences both good and bad. Such mutual assistance is valued since it reinforces well-being at work and can even overcome a teacher's possible isolation. These conclusions agree with those of Wimberley (2011), who associates climate of collaboration with professional well-being in teaching.

\subsubsection{Transfer}

Transfer is a variable that positively affects teachers' well-being and demonstrates the impact of their teaching; as such, it is feasible for both students and colleagues. In the first case, it occurs when students use content learned in PE during free periods in school or everyday life; in the second, it is when content taught during PE periods, or cognitive and motor skills learned by students, transfer to classrooms and life situations. These privileged moments nourish teachers' professional well-being because they demonstrate the impact of their structured and formalized teaching in other spheres of school and life. 


\subsection{School Administration}

The special place accorded the administration is directly linked to its role within the school. Here, the kind of leadership displayed is a key element of teachers' well-being. The style privileged is one that inspires all members of the school team to pursue a shared objective and adhere to the school's mission; hence, the kind of unifying approach conceptualized by Kouzes and Posner (1994). In terms of operationalization, such leadership may be characterized as the enhancement of professional autonomy; in other words, substantial freedom of action for professional proactivity and creativity. In complement to freedom of action, our findings are consistent with those in the literature to the effect that teachers appreciate the ongoing support of the school administration when it supports them in their choices and projects (Duchesne \& Savoie-Zajc, 2005; Levesque, Blais, \& Hess, 2004; Willmore, 2007).

\section{Conclusion}

In conclusion, this study enabled us to achieve our objective and identify different variables affecting the professional well-being of health and physical education teachers. Interestingly, the variables derive from distinct and interrelated categories and sub-categories. Further research is needed to discover teachers' conceptualizations of well-being and thereby determine if well-being is a situational condition that varies based on events, or an overall condition that tends to be stable over time.

\section{Acknowledgments}

The authors wish to thank Fonds de Recherche du Québec: Société et Culture and Groupe Interdisciplinaire de recherche en Santé Appliquée for their financial support.

\section{References}

Barbour, S., \& Kitzinger, J. (1999). Developing focus group research: Politics, theory, and practice. London: Sage publications. https://doi.org/10.4135/9781849208857

Brassell, D. (2015). Cultiver le plaisir d'enseigner. Montréal: Chenelière Éducation.

Cenkseven-Önder, F., \& Sari, M. (2009). The Quality of School Life and Burnout as Predictors of Subjective Well-Being among Teachers. Educational Sciences: Theory \& Practice, 9(3), 1223-1236

Csikszentmihalyi, M. (2008). Flow: The psychology of optimal experience. New York : Harper perennial.

Deslauriers, J.-P. (1991). Recherche qualitative: Guide pratique. Montréal: McGraw.

Duchesne, C., \& Savoie-Zajc, L. (2005). L'engagement professionnel d'enseignantes du primaire : une démarche inductive de théorisation. Recherches Qualitatives, 25(2), 69-95.

Duchesne, C., Savoie-Zajc, L., \& St-Germain, M. (2005). La raison d'être de l'engagement professionnel chez des enseignantes du primaire selon une perspective existentielle. Revue des sciences de l'éducation, 31(3), 497-518. https://doi.org/10.7202/013907ar

Gaucher, R. (2010). La psychologie positive ou l'étude scientifique du meilleur de nous-même. Paris: L'Harmattan.

Goyette, N. (2014). Le bien-être dans l'enseignement: étude des forces de caractère chez des enseignants persévérants du primaire et du secondaire dans une approche axée sur la psychologie positive. Thèse de doctorat. Université du Québec à Trois-Rivières (Trois-Rivières).

Goyette, N. (2016). Développer le sens du métier pour favoriser le bien-être en formation initiale à l'enseignement. Revue canadienne de l'éducation, 39(4), 3-30.

Houlfort, N., \& Sauvé, F. (2010). Santé psychologique des enseignants de la Fédération autonome de l'enseignement. Montréal : École nationale d'administration publique.

Huang, S.-Y. L., \& Waxman, H. C. (2009). The association of school environment to student teachers' satisfaction and teaching commitment. Teaching and Teacher Education, 25, 235-243. https://doi.org/10.1016/j.tate.2008.07.015

Janosz, M., Thiebaud, M., Bouthillier, C., \& Brunet, L. (2004). Perception du climat scolaire et epuisement professionnel chez les enseignants (pp. 1348-1356). Actes du XIIIème Congrès de Psychologie du Travail et des Organisations: Climat scolaire et épuisement professionnel, Centre de recherche et d'intervention sur la réussite scolaire (CRIRES).

Kamanzi, P., Barroso da Costa, C., \& Ndinga, P. (2017). Désengagement professionnel des enseignants canadiens: de la vocation à la désillusion. Une analyse à partir d'une modélisation par équations structurelles. McGill 
Journal of Education/Revue des sciences de l'éducation de McGill, 52(1), 115-134. https://doi.org/10.7202/1040807ar

Karsenti, T., Correa Molina, E. A., Desbiens, J.-F., Gauthier, C., Gervais, C., Lepage, M., ..., \& Collin, S. (2015). Analyse des facteurs explicatifs et des pistes de solution au phénomène du décrochage chez les nouveaux enseignants, et de son impact sur la réussite scolaire des élèves Rapport de recherche, programme actions concertées. Fonds de recherche Société et culture.

Kouzes, J. N., \& Posner, B. Z. (1994). Inventaire des pratiques de leadership. Montréal: Actualisation.

Lanthéaume, F., \& Hélou, C. (2008). La souffrance des enseignants. Une sociologie pragmatique du travail enseignant. Paris: PUF. https://doi.org/10.3917/puf.lanth.2008.01

Levesque, M., Blais, M. R., \& Hess, U. (2004). Dynamique motivationnelle de l'épuisement et du bien-être chez des enseignants africains. Revue canadienne des sciences du comportement, 36(3), 190-201. https://doi.org/10.1037/h0087229

Ministère de l'Éducation du Québec [MEQ]. (2001). Programme de formation de l'école québécoise. Éducation préscolaire, enseignement primaire. Québec: Gouvernement du Québec.

Morin, A., Breault-Labbé, A., \& Brassard, A. (2013). Conceptualisation multimodale de l'engagement professionnel et associations avec le bien-être chez des enseignants du primaire. Revue des sciences de l'éducation, 39(3), 571-595. https://doi.org/10.7202/1026313ar

Morin, E., \& Gagné, C. (2009). Donner un sens au travail- Poumouvoir le bien-être psychologique. Études et recherches. Rapport R-624. Montréal, IRSST.

Mukamurera, J., \& Balleux, A. (2013). Malaise dans la profession enseignante et identité professionnelle en mutation. Recherche et formation, 74, 57-70. https://doi.org/10.4000/rechercheformation.2129

Neufeld, G., \& Maté, G. (2005). Hold on to your kids. New York: Ballantine Books.

Ngoya, J. (2016). Étude des relations entre le développement professionnel des enseignants du postsecondaire et leur bien-être psychologique au travail. Thèse de doctorat. Département de psychopédagogie et d'andragogie, Faculté des Sciences de l'éducation, Université de Montréal (Montréal).

Ntsame, M. N., Desrumaux, P., \& Boudrias, J.-S. (2013). Bien-être au travail et motivation autodéterminée chez les enseignants. Les Cahiers Internationaux de Psychologie Sociale, 97(1), 69-87. https://doi.org/10.3917/cips.097.0069

Paillé, P., \& Mucchielli, A. (2008). L'analyse qualitative en sciences humaines et sociales. Paris: Armand Colin.

Peterson, C., \& Seligman, M. E. P. (2004). Character strengths and virtues: A handbook and classification. New York, NY: Oxford University Press.

Ryan, R. M., \& Deci, E. D. (2008). From ego depletion to vitality: Theory and findings concerning the facilitation of energy available to the self. Social and Personality Psychology Compass, 2(2), 702-717. https://doi.org/10.1111/j.1751-9004.2008.00098.x

Ryan, R. M., \& Frederick, C. (1997), On energy, personality and health: Subjective vitality as a dynamic reflection of well-being. Journal of Personality, 65, 529-565. https://doi.org/10.1111/j.1467-6494.1997.tb00326.x

Savoie-Zajc, L. (2009). L'entrevue semi-dirigée [The semi-directed interview]. In D. B. Gauthier (Éd.), Recherche sociale: de la problématique à la collecte des données ( $5^{\mathrm{e}}$ éd., pp. 337-360). Québec, QC: Presses de l'Université du Québec.

Seligman, M. (2002). Authentic happiness: Using the new positive psychology to realize your potential for lasting fulfillment. New York, NY: Free Press.

Seligman, M. (2011). A visionary new understanding of happiness and well-being: Flourish. Toronto: Atria.

St-Arnaud, Y. (2017). Le manque de moyens entraine de la détresse psychologique chez les enseignants. Huffingtonpost.

Retrieved

from https://quebec.huffingtonpost.ca/2017/11/22/le-manque-de-moyens-entraine-de-la-detresse-psychologique-c hez-les-enseignants_a_23285864/

Stamate, A.-N., Brunet, L., \& Savoie, A. (2015). La compétence en emploi peut-elle prédire la santé psychologique des enseignants? Le travail humain, 4(78), 355-378. https://doi.org/10.3917/th.784.0355 
Stoloff, S. (2016). Pour une gestion éducative du groupe-classe en éducation physique et à la santé. In B. Dans, D. Lenzen, B. Deriaz, H. Poussin, \& D. A. Cordoba (Éds.), Temps, temporalités et intervention en EPS et en sport (pp. 73-92). Bruxelles: Peter Lang.

Stoloff, S., Boulanger, M., Roy, V., \& Rivard, M.-C. (2015). Sensitization sessions as the foundations for training transformation activities. Journal of Education and Learning, 4(3), 146-154. https://doi.org/10.5539/jel.v4n3p146

Sturmfels, M. S. (2009). A Qualitative Study of Staff Stress, Morale and Well-being in Victorian Government Schools. Thèse de doctorat. School of Education, University of Melbourne (Melbourne).

Tardif, M. (2014). La condition enseignante au Québec du XIXe au XXIe siècle. Une histoire cousue de fils rouges: précarité, injustice et déclin de l'école publique. Québec, Québec : PUL.

Théorêt, M., \& Leroux, M. (2014). Comment améliorer le bien-être et la santé des enseignants? Des ressources pour la résilience éducationnelle. Louvain-la-Neuve, Belgique : De Boeck.

Van der Maren, J.-M. (2010). La maquette d'un entretien. Son importance dans le bon déroulement de l'entretien et dans la collecte de données de qualité. Recherches Qualitatives, 29(1), 129-139.

Vesely, A. K., Saklofske, D. H., \& Nordstokke, D. W. (2014). EI training and pre-service teacher wellbeing. Personality and Individual Differences, 65, 81-85. https://doi.org/10.1016/j.paid.2014.01.052

Wilmore, E. L. (2007). Teacher leadership. Thousand Oaks: Corwin Press.

Wimberley, C. E. (2011). Teacher Collaboration and Student Achievement. Thesis, Education Faculty of Lindenwood University.

Yildirim, K. (2014). Main factors of teachers' professional well-being. Educational Research and Reviews, 9(6), 153-163. https://doi.org/10.5897/ERR2013.1691

\section{Notes}

Note 1. Regarding the coding of items, FG1 stands for Focus Group no. 1 and $13 \mathrm{P} 17$ stands for the $13^{\text {th }}$ item of page 17. Each item is presented using the same coding principle.

Note 2. Names have been changed to preserve anonymity.

\section{Copyrights}

Copyright for this article is retained by the author, with first publication rights granted to the journal.

This is an open-access article distributed under the terms and conditions of the Creative Commons Attribution license (http://creativecommons.org/licenses/by/4.0/). 